\title{
Risk factors for diarrhea in a cohort of dairy heifer calves reared in individual outdoor hutches in Piraí, Rio de Janeiro, Brazil
}

\author{
Fatores de risco para diarreia em uma coorte de bezerras leiteiras \\ criadas em sistema de abrigos individuais em piquete, município de \\ Piraí, Rio de Janeiro, Brazil
}

\author{
Thais Ferreira Fagundes ${ }^{1}$; Letícia Gabriela Poblete Vidal'; \\ Pedro Afonso Moreira Alves ${ }^{3}$; Wagner de Souza Tassinari ${ }^{4}$; \\ Rita de Cássia Alves Alcântara de Menezes ${ }^{4}$; Adevair Henrique da Fonseca ${ }^{4}$; \\ Maria Julia Salim Pereira ${ }^{4 *}$
}

\begin{abstract}
This study aimed to evaluate the association between diarrhea and risk factors potentially related to diarrhea incidence, such as Cryptosporidium, Giardia, Eimeria and nematode infection, animal age, failure to transfer passive immunity, type of fertilization (artificial insemination - AI, in vitro production of embryos - IVP and natural breeding), mother (heifer/cow) and birth weight of heifer calves reared in individual outdoor hutches on a dairy farm. The database used in the present study refers to a weekly survey of a cohort of 118 heifer calves from birth to 100 days of age. A logistic generalized additive model (GAM) was fit to evaluate the functional relationship between the risk of diarrhea occurrence and birth weight. For analysis purposes, the database was divided into calves up to 30 days old and calves 31 to 100 days old. Bivariate and multivariate analyses were performed using logistic regression models via generalized estimating equations. All variables were included in the models and were removed oneby-one according to Wald statistics to obtain the final model. The relative risks (RR) and their respective $90 \%$ confidence intervals were estimated. The final model for calves up to 30 days old showed that IVP $[\mathrm{RR}=0.33(90 \% \mathrm{CI} 0.14 ; 0.75)]$ is a protective factor and that Cryptosporidium spp. infection $[\mathrm{RR}=1.95$ $(90 \%$ CI $1.22 ; 3.12)]$ is a risk factor. Although not statistically significant $[\mathrm{RR}=1.46(90 \% \mathrm{CI} 0.98$; 2.18)], failure to transfer passive immunity increases the risk of diarrhea. The final model for calves $31-$ 100 days old showed that IVP [RR=0.50 (90\% IC 0.28; 0.89)] and birth weight $\geq 40 \mathrm{~kg}[\mathrm{RR}=0.65(90 \%$ CI $0.47 ; 0.89)$ ] are protective factors. In this age group, Cryptosporidium spp. infection has no statistical significance $[\mathrm{RR}=1.25(90 \% \mathrm{CI} 0.95 ; 1.64)]$. These results indicate that some of the diarrhea episodes observed in animals up to 30 days old could be explained by Cryptosporidium infection; therefore, better monitoring of these animals is recommended. Greater care in colostrum administration is suggested because animals with hypoglobulinemia are more sensitive to diarrhea occurrence. Although attention should be given to all animals with a low birth weight, special care should be given to those 31 to 100 days old.
\end{abstract}

Key words: Epidemiology. Generalized estimating equations. Logistic regression model. Longitudinal study.

\footnotetext{
${ }^{1}$ Dr $^{\text {a }}$, Universidade Federal Rural do Rio de Janeiro, UFRRJ, Seropédica, RJ, Brasil. E-mail: tha.fagundes@gmail.com

2 Discente de Doutorado, UFRRJ, Seropédica, RJ, Brasil. E-mail: let_vet@yahoo.com.br

${ }^{3}$ Pesquisador, Estação Experimental de Seropédica, PESAGRO-RIO, Seropédica, RJ, Brasil. E-mail: gir.leiteiro2014@gmail.com

${ }^{4}$ Profs., UFRRJ, Seropédica, RJ, Brasil. E-mail: wtassinari@gmail.com; cassia@ufrrj.br; fonseca@ufrrj.br; m.salim@ufrrj.br

*Author for correspondence
} 


\title{
Resumo
}

\begin{abstract}
Este trabalho teve como objetivo estudar a associação entre a diarreia e os possíveis fatores de risco para sua incidência, tais como: infecção por Cryptosporidium, Giardia, Eimeria e nematóides, idade, falha na transferência de imunidade passiva, tipo de fertilização (Inseminação artificial - IA, Produção in vitro de embriões - PIVE e monta natural), mãe (novilha/vaca) e peso ao nascer, em bezerras criadas sob sistema de abrigo individual em piquete, em uma fazenda de produção leiteira. O banco de dados utilizado refere-se ao acompanhamento semanal de uma coorte de 118 bezerras do nascimento aos cem dias de idade. Um modelo logístico aditivo generalizado (GAM) foi ajustado para avaliar a relação funcional entre o risco de ser acometido por diarreia e o peso ao nascer. Para fins de análise, o banco de dados foi dividido em bezerras até 30 dias de idade e de 31 a 100 dias de idade. Análises bivariadas e multivariadas foram realizadas utilizando-se os modelos de regressão logística via equações estimadas generalizadas. Todas as variáveis foram incluídas nos modelos, sendo retiradas uma a uma, segundo a estatística de Wald, até a obtenção do modelo final. Foram estimados os riscos relativos (RR) e seus respectivos intervalos com $90 \%$ de confiança. O modelo final para bezerras com até 30 dias de idade mostrou evidências de que o tipo de fertilização PIVE [RR=0,33 (IC 90\% 0,14; 0,75)] é um fator de proteção e a infecção por Cryptosporidium spp. [RR=1,95 (IC 90\% 1,22; 3,12)] um fator de risco. Embora, sem significância estatística $[\mathrm{RR}=1,46$ (IC $90 \% 0,98 ; 2,18$ )], a falha na transferência de imunidade passiva aumenta o risco de diarreia. $\mathrm{O}$ modelo final, para bezerras de 31 a 100 dias de idade, mostrou evidências de que PIVE [RR=0,50 (IC 90\% 0,28; 0,89)] e peso ao nascer $\geq 40 \mathrm{~kg}[\mathrm{RR}=0,65$ (IC 90\% 0,47; 0,89)] são fatores de proteção. Nesta faixa etária, a infecção por Cryptosporidium spp não tem significância estatística $[\mathrm{RR}=1,25$ (IC 90\% 0,95; 1,64)]. Estes resultados indicam que parte da diarreia observada na faixa etária até 30 dias pode ser explicada pela infecção por Cryptosporidium, recomendando-se um melhor acompanhamento dos animais. Sugere-se maior cuidado na administração do colostro, visto que animais com hipoglobulinemia são mais sensíveis à ocorrência de diarreia. Embora, deva ser dispensada atenção a todos os animais com baixo peso ao nascer, especial cuidado deve ser dado àqueles na faixa etária de 31 a 100 dias.
\end{abstract}

Palavras-chave: Epidemiologia. Equações estimadas generalizadas. Modelo de regressão logistica. Estudo longitudinal.

\section{Introduction}

Diarrhea is a major health problem in calves (SIVULA et al., 1996) because it can cause delayed growth, mortality, older age at first calving and, consequently, direct and/or indirect economic losses (DE GRAAF et al., 1999; HASCHEK et al., 2006; TZIPORI, 1981). In addition to the economic losses, risks for public health should be considered, due to the zoonotic characteristics of some causal agents and the residues of antibiotics and other drugs used for their control (FRANK; KANEENE, 1993).

Diarrhea in calves has multifactorial etiology in which viruses, bacteria, protozoans and even management may be the cause, in addition to environmental, nutritional, immunological and, possibly, genetic factors (DE GRAAF et al., 1999; HASCHEK et al., 2006; TZIPORI, 1981).
Morbidity and mortality due to respiratory and intestinal infections in calves are attributed to a failure to transfer passive immunity (BOYD, 1972; FURMAN-FRATCZAK et al., 2011; TENNANT et al., 1979). Although failure to transfer passive immunity is considered a risk factor for calf health by some authors (FURMAN-FRATCZAK et al., 2011; SVENSSON et al., 2003; WINDEYER et al., 2014), there are others controversial research findings (PIMENTA-OLIVEIRA et al., 2011; SIVULA et al., 1996).

The technique of in vitro production of embryos (IVP) was related to higher rates of stillbirths and perinatal mortality (NUMABE et al., 2000). However, Pimenta-Oliveira et al. (2011) reported no influence of this fertilization technique, on the health status and performance of Brahman calves, which exhibited weaning weights similar to those 
of animals, produced using artificial insemination (AI). Nevertheless, the gestation period and the birth weight differed between calves born by IVP and those born by AI.

The type of calf housing system was also related to mortality and diarrhea in newborn calves (BOTTEON et al., 2008; MACHADO NETO et al., 2004). In Brazil, to minimize the health problems related to calf housing systems, some dairy farms use individual outdoor calf hutches, which have several advantages, such as protection against excessive rain and sun, ease of cleaning and movement, and the avoidance of moisture accumulation (OLIVEIRA et al., 2005).

In the state of Rio de Janeiro, Brazil, Fagundes et al. (2014) reported a high incidence of diarrhea, in calves reared in individual outdoor calf hutches on a dairy farm. However, despite the increasing use of this system in dairy farms, there are no studies on risk factors for diarrhea incidence in these calves.

There are several cross-sectional studies on the occurrence of diarrhea and Giardia, Cryptosporidium, Eimeria and helminthic infections in cattle (BARTELS et al., 2010; BARWICK et al., 2003; GEURDEN et al., 2012; JIMÉNEZ et al., 2010; MUHID et al., 2012; PÉREZ et al., 1998). As well as studies on the risk factors for protozoan infection; these studies identified diarrhea as a consequence of all these infections (GARBER et al., 1994; MALDONADO-CAMARGO et al., 1998; MOHAMMED et al., 1999). However, crosssectional studies have temporality issues that hinder understanding regarding which variables are the causal variables and which are exposure variables. Thus, whenever possible, longitudinal studies should be performed (DOHOO et al., 2003). In this sense, the aim of the present study was to evaluate the association between diarrhea and possible risk factors for its incidence, such as protozoan and/or helminth infection, animal age, colostrum absorption, type of fertilization, and mother and birth weight of a cohort of calves reared in individual outdoor calf hutches on a dairy farm in the municipality of Piraí, Rio de Janeiro state, Brazil.

\section{Materials and Methods}

\section{Data source}

A database built by Fagundes et al. (2014), through weekly follow-up of a cohort of 118 heifer calves from birth to 100 days old, from September 2009 to June 2011, was used in the present study. All heifer calves born in that period were included in the cohort. The calves had different proportions of black and white Holstein blood and belonged to a dairy farm located in the municipality of Piraí (latitude $22^{\circ} 37^{\prime} 45^{\prime \prime}$ south and longitude 43⒌'53" west, 387 meters above sea level), Rio de Janeiro, Brazil.

Briefly, the farm management consisted of free-stall facilities for lactating cows and individual outdoor calf hutches for calves up to 100 days old, which were separated from their mothers immediately after birth. In the hutches, the calves received a total of six litters of colostrum, via bottle on two different occasions, thawed at the time of administration. The colostrum was selected from specific cows using a colostrometer test and stored in the freezer. The calves were given milk, cattle food and water (from an artesian well) until they were 90 days old. Calves 91 to 100 days old were given feed and water only. The buckets used for milk, feed and water were cleaned with water in the morning. As part of the farm management, the navel treatment was performed with iodized alcohol. Doramectin $^{5}$ (once a month), sodium sulfamethazine ${ }^{6}$ and oxytetracycline ${ }^{7}$ with diazoaminodibenzamidine diaceturate $^{8}$ were administered to prevent and treat parasitic nematode and arthropod infections and remedy severe diarrhea and tick fever, respectively.

${ }^{5}$ Dectomax ${ }^{\circledR}-1 \%$ injectable solution, Pfizer Saúde Animal, Guarulhos, SP, Brazil

${ }^{6}$ Biosulfan ${ }^{\circledR}$ - injectable solution, Biofarm Química e Farmacêutica, Jaboticabal, SP, Brazil

7 Terramicina ${ }^{\circledR} /$ LA injectable solution, Pfizer Saúde Animal, Guarulhos, SP, Brazil

${ }^{8}$ Diaseg ${ }^{\circledR}$ 7\% injectable solution, Schering-Plough Veterinária, Cotia, SP, Brazil 
The method used by Fagundes et al. (2014) to obtain the data analyzed in the present study will be briefly described. Feces were collected, the calves were weighed, diarrhea episodes and other clinical alterations were recorded and blood from newborn calves was collected during weekly visits to the farm.

The feces samples were classified by the same observer as "normal" when the consistency was firm, the color was brown and the calf perineum and tail were dry and clean; the samples were considered "diarrheal" when the consistency was pasty or watery and the calf perineum and/or tail were dirty with feces.

The diagnoses of Cryptosporidium spp. and Giardia spp. infection were performed using the formalin-ether centrifuge-sedimentation technique (BASSO et al., 1998). The intensity of Cryptosporidium spp. and Giardia spp. infection was classified semi-quantitatively according to the number of oocysts/cysts per field from a total of 20 randomly selected fields at $1,000 \mathrm{X}$ magnification. The classification categories were absence of cysts, low intensity (1 cyst), moderate intensity ( $2-5$ cysts), high intensity (6-10 cysts) and very high intensity (>10 cysts) (CASTROHERMIDA et al., 2002).

The number of Eimeria oocysts per gram of feces (EoPG) and the number of nematode eggs per gram of feces (EPG) were counted using the saturated sugar flotation technique (density 1.20 to 1.25) as described by Menezes and Lopes (1995). Nematode-positive samples were separated for fecal cultures (ROBERTS; O'SULLIVAN, 1950) and subsequent identification of the nematode genera (UENO; GONÇALVES, 1998).

The intensity of the Eimeria spp. infection was considered moderate when the EoPG ranged from 5-700 and high when $>700$. A portion of the feces of each calf positive for Eimeria spp. was subjected to the sporulation process described by Matjila and Penzhorn (2002), followed by percentage identification of species, according to the criteria described by Eckert et al. (1995) and Levine (1985).

Blood samples from all calves 0 to 13 days old were collected at least six hours after the ingestion of colostrum for the evaluation of the transference of passive immunity using the glutaraldehyde coagulation test (CHARLES et al., 1994). The reactions were considered positive when there was formation of a firm, opaque mass in the tube bottom (1.46 $\mathrm{g}$ of immunoglobulin/dl on average); incomplete when there was formation of a semi-solid mass ( $0.6 \mathrm{~g}$ of immunoglobulin/dl on average); and negative when there were no detectable changes in the serum $(0.18 \mathrm{~g}$ of immunoglobulin/dl on average) (CHARLES et al., 1994). Because the solidification reaction depends on the immunoglobulin concentration, which may occur late (TENNANT et al., 1979), the results of the glutaraldehyde coagulation test were obtained 60 minutes after the addition of the reagent to the serum.

Data regarding the date of birth, birth weight, type of fertilization and mother (heifer or cow) were obtained from the farm records.

\section{Statistical analysis}

The presence/absence of diarrhea in the population was defined as the outcome variable to be adjusted according to the following explanatory variables: type of fertilization (AI, IVP or controlled mating), mother (heifer or cow), colostrum absorption (positive, incomplete or negative), birth weight (kg), and Cryptosporidium, Giardia, Eimeria and nematode infection (positive and negative).

To assess the functional relationship between the animal's risk of being affected by diarrhea and the continuous variable birth weight, a logistic 
generalized additive model (GAM) was fit (HIN et al, 1999; WOOD, 2006). This model is used as a technique to obtain cutoff points to categorize continuous quantitative variables for better interpretability and control of possible bias effects.

The database was stratified according to the calves' ages, and two age groups were formed: one group with calves up to 30 days old and another group with calves from 31 to 100 days old. This stratification is necessary because the risk of diarrhea varies with animal age and is higher in the first weeks of life (FAGUNDES et al., 2014).

For analysis purposes, the variables Cryptosporidium, Giardia, Eimeria and nematode infection were re-classified according to the semiquantitative results (low, moderate, high infection intensity) and the EoPG/EPG results and were thus considered as positive or negative samples.

Bivariate and multivariate analyses of the possible factors involved in diarrhea occurrence were performed by logistic regression using generalized estimating equations (GEE). These models were chosen, because this is a longitudinal study and thus assumes the existence of some autocorrelation structure, between the measures from the same animals obtained during the experimental period. Such structure can vary according to natural sources or the genetic predisposition of the studied animals. The GEE was first proposed by Liang and Zeger (1986) and can be thought of as an extension of the Generalized Linear Models - GLM (NELDER; WEDDERBURN, 1972) that includes a "working" correlation matrix.

A working correlation matrix represents how the observations within each group are correlated. According to Katz (2006), the most common correlation matrices in epidemiology are as follows: autoregressive - assumes that the correlation within a cluster decreases as the distance between the observations increases; uniform - assumes that two observations within a cluster have the same correlation; independent - assumes that the repeated observations within a cluster are not correlated; and unstructured - makes no assumptions about the correlation of observations within a cluster. In the present study, the models were fit with the working correlation matrix structures: autoregressive, uniform, independent and unstructured. The choice was made using the correlation information criterion (CIC) proposed by Hin and Wang (2009), considering that the correlation matrix with the lower CIC is the most appropriate.

All variables were initially included in the model, called a full model, and were removed oneby-one according to Wald statistics (HARRELL, 2001). Simultaneously, during this procedure, the biological plausibility of each of the variable effects regarding the outcomes was also assessed as suggested by Katz (2006). The relative risks (RR) and their respective 90\% confidence intervals were estimated based on the regression coefficients.

To assess the quality of the model fit, the Quasilikelihood under the Independence Model Criterion (QIC) proposed by Pan (2001) and Cui (2007) was used. According to this criterion, the model with the lowest QIC value is the best-fitted model.

All statistical analyses were performed with the aid of R statistical software (R DEVELOPMENT CORE TEAM, 2011), and the gee (CAREY et al., 2012) and geepack packages (HØJSGAARD et al., 2006; YAN, 2002; YAN; FINE, 2004) were used to fit the GEE models.

\section{Results}

The analysis of the generalized additive model showed an increasing linear relationship between diarrhea and birth weight (Figure 1). Thus, the variable birth weight was dichotomized (less than $40 \mathrm{~kg}$ and greater than or equal to $40 \mathrm{~kg}$ ). 
Figure 1. Logistic generalized additive model for the study of the functional relationship between the risk of the animal having diarrhea and birth weight of calves.

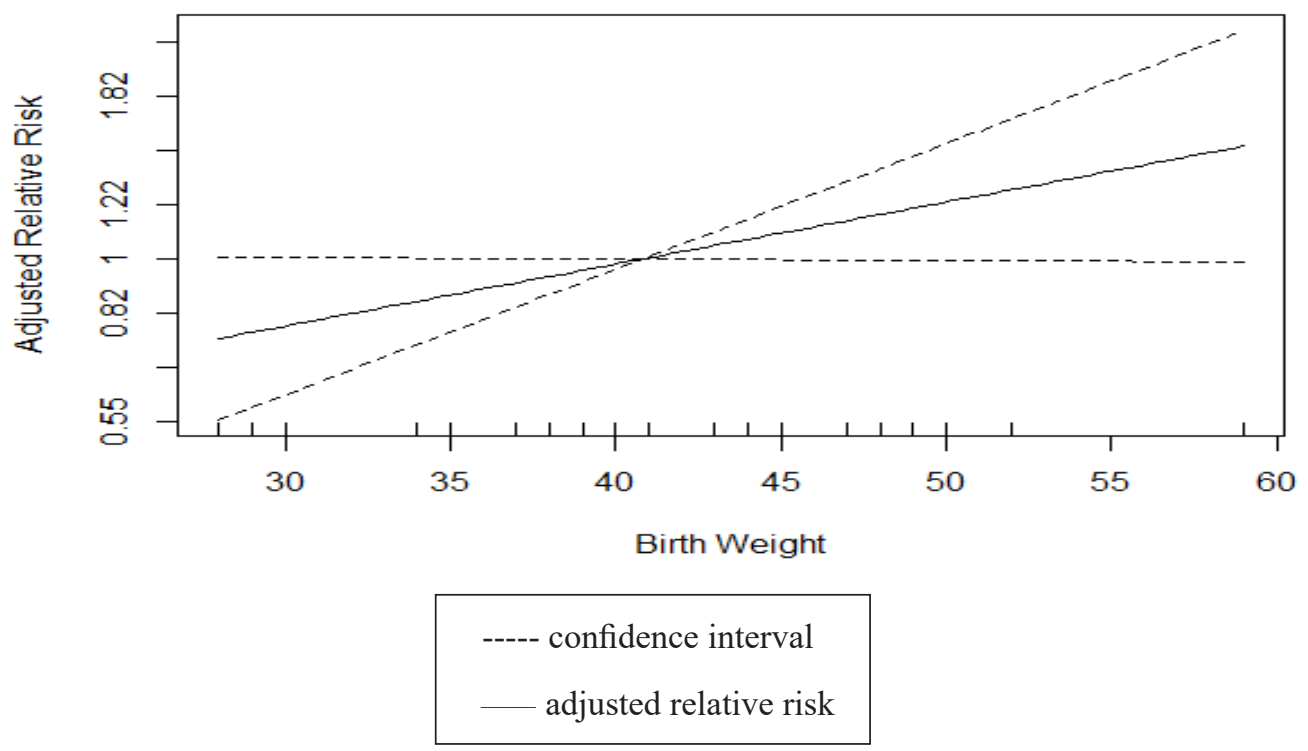

The most appropriate working correlation matrix was the unstructured matrix (Table 1) for both the database extract that included calves up to 30 days old and the extract for calves 31 to 100 days old; the unstructured matrix was adopted in all of the following analyses.

Table 1. Working correlation matrix structures and correlation information criterion (CIC) values estimated by the full logistic regression models using generalized estimating equations for calves up to 30 days old and calves 31 to 100 days old.

\begin{tabular}{ccccc}
\hline \multirow{3}{*}{ Age (days) } & \multicolumn{4}{c}{ Correlation Structure } \\
\cline { 2 - 5 } & Autoregressive & Uniform & Independent & Unstructured \\
\cline { 2 - 5 } & \multicolumn{4}{c}{ CIC Values } \\
\hline Up to 30 & 10.05 & 10.03 & 10.00 & 9.61 \\
31 to 100 & 16.64 & 16.43 & 16.37 & 15.90 \\
\hline
\end{tabular}

Only the variables type of fertilization, Cryptosporidium infection and colostrum absorption (results of the glutaraldehyde coagulation test) were significant in the bivariate analysis of animals that were up to 30 days old. For calves that were 31 to 100 days old, only the variable birth weight greater than or equal to $40 \mathrm{~kg}$ was significant in the bivariate analysis (Table 2).

The model fits from the full model for the age group up to 30 days old are shown in Table 3. For this age group, the variables type of fertilization (in the category IVP) and Cryptosporidium infection were statistically significant for diarrhea occurrence (model 7). The model 7 had a better fit, but the model 6 was chosen because of the biological plausibility of the variable glutaraldehyde coagulation test, although it was not statistically significant ( $p$-value=0.12). In the final model, there is evidence that IVP is a protective factor and that Cryptosporidium infection is a risk factor for 
animals up to 30 days old (Table 4).

The model fits from the full model for calves from 31 to 100 days old are shown in Table 5, which also shows that the variables type of fertilization (IVP) and birth weight greater than or equal to $40 \mathrm{~kg}$ were significant up to the seventh model fitted. However, the QIC value increased, showing that the previous model (model 6) is a better fit. Model 6 includes the same variables as those of model 7 and the variable elimination of Cryptosporidium oocysts. Model 6 was thus chosen as the final model. In the final model (Table 6), there is statistical evidence that IVP and a birth weight greater than or equal to $40 \mathrm{~kg}$ are protective factors, while Cryptosporidium infection ceases to be a statistically significant risk factor $(p$-value $=0.18)$ for calves 31 to 100 days old. However, the variable Cryptosporidium infection was maintained because it improves the model fit and suggests an increased risk of diarrhea.

Table 2. Bivariate analysis of the relative risk (RR) of diarrhea incidence in calves from birth to 100 days of age.

\begin{tabular}{|c|c|c|c|c|c|}
\hline \multirow{3}{*}{ Variable } & \multirow{3}{*}{ Category } & \multicolumn{4}{|c|}{ Age (days) } \\
\hline & & \multicolumn{2}{|l|}{ Up to 30} & \multicolumn{2}{|l|}{$31-100$} \\
\hline & & $\mathrm{RR}[90 \% \mathrm{CI}]$ & $\mathrm{p}$-value & $\mathrm{RR}[90 \% \mathrm{CI}]$ & $\mathrm{p}$-value \\
\hline \multirow{2}{*}{ Mother } & cow (ref.) & - & & - & \\
\hline & heifer & $0.86[0.59-1.20]$ & 0.51 & $0.88[0.63-1.22]$ & 0.52 \\
\hline \multirow{3}{*}{ Fertilization } & Controlled mating (ref.) & & & & \\
\hline & $\mathrm{IVP}^{* *}$ & $0.37[0.14-0.94]$ & $0.07 *$ & $0.75[0.43-1.29]$ & 0.38 \\
\hline & $\mathrm{AI}^{* * *}$ & $0.85[0.53-1.37]$ & 0.57 & $1.40[0.87-2.29]$ & 0.26 \\
\hline \multirow{2}{*}{ Cryptosporidium } & negative (ref.) & - & & - & \\
\hline & positive & $1.80[1.13-2.87]$ & $0.03 *$ & $1.22[0.93-1.60]$ & 0.22 \\
\hline \multirow{2}{*}{ Giardia } & negative (ref.) & - & & - & \\
\hline & positive & $0.77[0.48-1.23]$ & 0.36 & $0.80[0.58-1.11]$ & 0.27 \\
\hline \multirow{2}{*}{ Eimeria } & negative (ref.) & - & & - & \\
\hline & positive & $0.96[0.65-1.43]$ & 0.89 & $0.90[0.72-1.12]$ & 0.43 \\
\hline \multirow{3}{*}{$\begin{array}{l}\text { Glutaraldehyde } \\
\text { coagulation test }\end{array}$} & positive (ref.) & - & & - & \\
\hline & incomplete & $1.31[0.71-2.42]$ & 0.46 & $0.89[0.55-1.46]$ & 0.71 \\
\hline & negative & $1.48[1.00-2.19]$ & $0.09^{*}$ & $1.21[0.78-1.88]$ & 0.47 \\
\hline \multirow{2}{*}{ Nematodes } & negative (ref.) & - & & - & \\
\hline & positive & $0.49[0.13-1.81]$ & 0.37 & $0.76[0.55-1.05]$ & 0.17 \\
\hline \multirow{2}{*}{ Birth weight $(\mathrm{kg})$} & $<40$ (ref.) & - & & - & \\
\hline & $\geq 40$ & $1.05[0.72-1.53]$ & 0.83 & $0.69[0.51-0.94]$ & $0.05^{*}$ \\
\hline
\end{tabular}

* significant variable ( $\mathrm{p}$-value $<0.10$ ); **in vitro production of embryos; $* * *$ artificial insemination; $\mathrm{CI}=$ confidence interval; ref.=reference. 
Table 3. Logistic regression models using generalized estimating equations of the risk of incidence of diarrhea in calves from birth to 30 days old, for the verification of the quasi-likelihood under the independence model criterion (QIC) with the respective $\mathrm{p}$-values $(\alpha=10 \%)$.

\begin{tabular}{|c|c|c|c|c|c|c|c|c|}
\hline \multirow{2}{*}{ Variable } & \multirow{2}{*}{ Category } & \multicolumn{7}{|c|}{ Model/p-value } \\
\hline & & 1 & 2 & 3 & 4 & 5 & 6 & 7 \\
\hline \multirow{2}{*}{ Mother } & cow (ref.) & & & & & & & \\
\hline & $\begin{array}{l}\text { Heifer } \\
\text { controlled mating (ref.) }\end{array}$ & 0.25 & 0.25 & 0.25 & 0.26 & 0.28 & - & - \\
\hline \multirow[t]{2}{*}{ Fertilization } & IVP** & $0.02 *$ & $0.02 *$ & $0.02 *$ & $0.01 *$ & $0.01 *$ & $0.02 *$ & $0.03 *$ \\
\hline & $\mathrm{AI}^{* * *}$ & 0.46 & 0.46 & 0.56 & 0.56 & 0.52 & 0.61 & 0.59 \\
\hline Cryptosporidium & $\begin{array}{l}\text { negative (ref.) } \\
\text { Positive } \\
\text { negative (ref.) }\end{array}$ & $0.02 *$ & $0.02 *$ & $0.02 *$ & $0.02 *$ & $0.02 *$ & $0.02 *$ & $0.02 *$ \\
\hline Giardia & $\begin{array}{l}\text { Positive } \\
\text { negative (ref.) }\end{array}$ & 0.48 & 0.47 & 0.47 & - & - & - & - \\
\hline Eimeria & $\begin{array}{l}\text { Positive } \\
\text { negative (ref.) }\end{array}$ & 0.90 & - & - & - & - & - & - \\
\hline Nematodes & Positive & 0.45 & 0.45 & 0.44 & 0.45 & - & - & - \\
\hline Birth weight & $\begin{array}{l}<40 \text { (ref.) } \\
\geq 40 \mathrm{~kg} \\
\text { positive (ref.) }\end{array}$ & 0.53 & 0.52 & - & - & - & - & - \\
\hline \multirow{2}{*}{$\begin{array}{l}\text { Glutaraldehyde } \\
\text { coagulation test }\end{array}$} & Incomplete & 0.64 & 0.64 & 0.65 & 0.66 & 0.65 & 0.54 & - \\
\hline & Negative & 0.12 & 0.12 & 0.15 & 0.15 & 0.13 & 0.12 & - \\
\hline QIC & & 432.40 & 430.48 & 429.48 & 427.94 & 426.71 & 425.99 & 424.21 \\
\hline
\end{tabular}

$*$ significant variable (p-value $<0.10)$; **in vitro production of embryos; $* * *$ artificial insemination; ref. $=$ reference.

Table 4. Final logistic regression model using generalized estimating equations for relative risk (RR) of incidence of diarrhea in calves from birth to 30 days old.

\begin{tabular}{lccc}
\hline Variable & Category & RR [90\% CI $]$ & p-value \\
\hline Fertilization & IVP** & $0.33[0.14-0.75]$ & $0.02^{*}$ \\
Glutaraldehyde coagulation test & Negative & $1.46[0.98-2.18]$ & 0.12 \\
Cryptosporidium & Positive & $1.95[1.22-3.12]$ & $0.02 *$ \\
\hline
\end{tabular}

* significant variable ( $\mathrm{p}$-value $<0.10) ; * *$ in vitro production of embryos; $\mathrm{CI}=$ confidence interval. 
Table 5. Logistic regression models using generalized estimating equations of the risk of incidence of diarrhea in calves that were 31 to 100 days old, for the verification of the quasi-likelihood under the independence model criterion (QIC) with the respective $p$-values $(\alpha=10 \%)$.

\begin{tabular}{|c|c|c|c|c|c|c|c|c|}
\hline \multirow{2}{*}{ Variable } & \multirow{2}{*}{ Category } & \multicolumn{7}{|c|}{ Model/p-value } \\
\hline & & 1 & 2 & 3 & 4 & 5 & 6 & 7 \\
\hline \multirow{2}{*}{ Mother } & cow (ref.) & & & & & & & \\
\hline & $\begin{array}{l}\text { Heifer } \\
\text { controlled mating (ref.) }\end{array}$ & 0.40 & 0.40 & - & - & - & - & - \\
\hline \multirow[t]{2}{*}{ Fertilization } & IVP** & $0.02 *$ & $0.02 *$ & $0.05^{*}$ & $0.04^{*}$ & $0.06^{*}$ & $0.05^{*}$ & $0.06^{*}$ \\
\hline & $\mathrm{AI}^{* * *}$ & 0.59 & 0.60 & 0.53 & 0.53 & 0.54 & 0.56 & 0.55 \\
\hline \multirow{2}{*}{ Cryptosporidium } & negative (ref.) & & & & & & & \\
\hline & $\begin{array}{l}\text { Positive } \\
\text { negative (ref.) }\end{array}$ & 0.17 & 0.15 & 0.16 & 0.18 & 0.18 & 0.18 & - \\
\hline Giardia & $\begin{array}{l}\text { Positive } \\
\text { negative (ref.) }\end{array}$ & 0.35 & 0.31 & 0.30 & - & - & - & - \\
\hline Eimeria & $\begin{array}{l}\text { Positive } \\
\text { negative (ref.) }\end{array}$ & 0.47 & - & - & - & - & - & - \\
\hline Nematodes & Positive & 0.22 & 0.21 & 0.22 & 0.23 & 0.19 & - & - \\
\hline \multirow{2}{*}{ Birth weight } & $<40$ (ref.) & & & & & & & \\
\hline & $\begin{array}{l}\geq 40 \mathrm{~kg} \\
\text { positive (ref.) }\end{array}$ & $0.03 *$ & $0.03 *$ & $0.02 *$ & $0.02 *$ & $0.04 *$ & $0.03 *$ & $0.03 *$ \\
\hline \multirow{2}{*}{$\begin{array}{l}\text { Glutaraldehyde } \\
\text { coagulation test }\end{array}$} & Incomplete & 0.55 & 0.50 & 0.56 & 0.58 & - & - & - \\
\hline & Negative & 0.21 & 0.23 & 0.22 & 0.23 & - & - & - \\
\hline QIC & & 1277.5 & 1277.8 & 1274.3 & 1273.2 & 1264.1 & 1261.6 & 1262.2 \\
\hline
\end{tabular}

* significant variable $(\mathrm{p}$-value $<0.10) ; *$ in vitro production of embryos; *** artificial insemination

Table 6. Final logistic regression model using generalized estimating equations for the relative risk (RR) of incidence of diarrhea in calves from 31 to 100 days old.

\begin{tabular}{lccc}
\hline Variable & Category & RR [90\% CI $]$ & p-value \\
\hline Fertilization & IVP** & $0.50[0.28-0.89]$ & $0.05^{*}$ \\
Birth weight & $\geq 40 \mathrm{~kg}$ & $0.65[0.47-0.89]$ & $0.03^{*}$ \\
Cryptosporidium & Positive & $1.25[0.95-1.64]$ & 0.18 \\
\hline
\end{tabular}

* significant variable ( $\mathrm{p}$-value $<0.10$ ); ** in vitro production of embryos; $\mathrm{CI}=$ confidence interval.

\section{Discussion}

In this study, the presence of Cryptosporidium oocysts in feces of calves 0 to 30 days old was a risk factor for diarrhea occurrence, which is consistent with the life cycle of this protozoan and affects animals in this age group. Moreover, these results are consistent with the reports of Mohammed et al. (1999), who observed a significant association between, age and risk of infection only for calves under 30 days old, in a study that established the 
risk factors for Cryptosporidium spp. infection in cattle.

Efficient ingestion and absorption of colostrum is a protective factor against diarrhea (RIBEIRO et al., 1983). However, there are some controversial results. Although no difference in mortality and morbidity has been reported between animals with adequate or inadequate transfer of passive immunity (SIVULA et al., 1996), higher incidences of diarrhea and respiratory diseases were observed in calves who breastfed colostrum from secondlactation cows and were born at night (SVENSSON et al., 2003).

Additionally, a higher incidence of disease $(81.8 \%)$ was reported in calves with failure to absorb colostrum than in calves with optimal absorption (26.7\%) (FURMAN-FRATCZAK et al., 2011). In the present study, failure to transfer passive immunity did not remain significantly associated with diarrhea incidence when controlling for other factors, which was also observed by Windeyer et al. (2014). These differences in the results, in part, can be due to the methodology employed in the detection of failure to transfer passive immunity, the sample size (small sample reduces the power to detect any minor differences) and the statistic techniques used.

Nevertheless, in the present study, insufficient absorption of colostrum is considered to have clinical relevance because negative calves for the glutaraldehyde coagulation test and those with incomplete reactions had increased risk of diarrhea, $\mathrm{RR}=1.46$ [90\% CI 0.98; 2.18] and $\mathrm{RR}=1.25$ [90\% CI $0.69 ; 2.27]$, respectively. In cattle, passive immunity depends exclusively on the intestinal absorption of immunoglobulins during the first hours after birth (BRIGNOLE; STOTT, 1980). Considering that the colostrum bottle-fed to the calves was from a collection with quality control, the observed immunoglobulin deficit may be in part due to the influence of increased release of adrenaline when the colostrum was provided to the animals. This may have occurred due to the air temperature, humidity, or presence of pain, fear or apprehension, which, according to Stott et al. (1976), may influence the amount of immunoglobulins absorbed.

Additionally, Pimenta-Oliveira et al. (2011) observed that the type of fertilization does not affect the transfer of passive immunity or animal health. On the other hand, animals born from IVP were more resistant to diarrhea in both age groups evaluated in the present study, possibly due to the rigorous selection of parents and embryos generated, as only the most viable samples are used.

In calves aged between 31 and 100 days old, the risk of diarrhea was not significantly associated with Cryptosporidium infection, which reinforces the importance of this protozoan in younger animals (GARBER et al., 1994; QUÍLEZ et al., 1996). For animals 31 to 100 days old, birth weight is a significant protective factor, i.e., higher birth weights and lower mortality rates during the rearing period (RAY, 1972). In calves, birth weight is the first information that indicates the vigor and prenatal development of the animal. Low birth weights are undesirable because they are related to increased mortality rates in the pre-weaning phase. In contrast, high birth weights tend to increase the occurrence of dystocia in herds (SCARPATI; LÔBO, 1999), which, in turn, affects the transfer of passive immunity. None of the calves included in the present study was born in dystocia, and there was only one case of twin calves. Both survived during the entire study, showing no clinical signs. According to Wells et al. (1996), calves born in dystocia were 4.2 times more likely to die in the first 21 days of life compared to animals that were born in a natural birth; twin calves were 1.9 times more likely to die in the first 21 days of life than single calves.

Although the calves were confined to hutches in which they had no contact with each other until they reached 100 days old, Cryptosporidium infection is a risk factor for diarrhea in calves 
up to 30 days old. This fact is most likely due to poor management of the hutches, as reported by Fagundes et al. (2014).

\section{Conclusions}

In conclusion, considering the absence of enteropathogenic Escherichia coli and enteroinvasive E.coli (FAGUNDES et al., 2014) in the herd and the limitations of the present study, since not all of the possible factors and biological agents identified as causing diarrhea in calves were assessed, the results obtained indicate that some of the diarrhea episodes observed in the studied population, in the age group up to 30 days old, can be explained by Cryptosporidium infection. Therefore, better monitoring of these animals is recommended. In addition, greater care must also be given to colostrum administration because animals with hypoglobulinemia are more sensitive to diarrhea occurrence. Additionally, animals born weighing less than $40 \mathrm{~kg}$ should receive special care.

\section{Acknowledgements}

Thanks to the Brazilian National Agency for the Support and Evaluation of Graduate Education (Coordenação de Aperfeiçoamento de Pessoal de Nível Superior - CAPES) and the Rio de Janeiro Research Foundation (Fundação Carlos Chagas Filho de Amparo à Pesquisa do Estado do Rio de Janeiro - FAPERJ) (process E-26/110.228/2010APQ1).

\section{References}

BARTELS, C. J. M.; HOLZHAUER, M.; JORRITSMA, R.; SWART, W. A. J. M.; LAM, T. J. G. M. Prevalence, prediction and risk factors of enteropathogens in normal and non-normal faeces of young Dutch dairy calves. Preventive Veterinary Medicine, Amsterdam, v. 93, n. 2-3, p. 162-169, 2010.
BARWICK, R. S.; MOHAMMED, H. O.; WHITE, M. E.; BRYANT, R. B. Prevalence of Giardia spp. and Cryptosporidium spp. on dairy farms in southeastern New York state. Preventive Veterinary Medicine, Amsterdam, v. 59, n. 1, p. 1-11, 2003.

BASSO, W. U.; VENTURINI, L.; RISSO, M. A. Comparación de técnicas parasitológicas para el examen de perro. Parasitología al Día, Santiago, v. 22, n. 1-2, p. 52-56, 1998.

BOTTEON, R. C. C. M.; BOTTEON, P. T. L.; SANTOS JÚNIOR, J. C. B.; PINNA, M. H.; LÓSS, Z. G. Frequência de diarréia em bezerros mestiços sob diferentes condições de manejo na região do médio Paraíba - Rio de Janeiro e Minas Gerais. Brazilian Journal of Veterinary Research and Animal Science, São Paulo, v. 45, n. 2, p. 153-162, 2008.

BOYD, J. W. The relationship between serum immune globulin deficiency and disease in calves: a farm survey. Veterinary Record, London, v. 90, n. 23, p. 645-649, 1972.

BRIGNOLE, T. J.; STOTT, G. H. Effect of suckling followed by bottle feeding colostrums on immunoglobulin absorption and calf survival. Journal of Dairy Science, Champaign, v. 63, n. 3, p. 451-456, 1980.

CAREY, V. J.; LUMLEY, T.; RIPLEY, B. Gee: generalized estimation equation solver.2012. Available at: $\quad<$ http://cran.r-project.org/web/packages/gee/index. html>. Accessed at: 12 jul. 2012.

CASTRO-HERMIDA, J. A.; GONZÁLEZ-LOSADA, Y. A.; MEZO-MENÉNDEZ, M.; ARES-MAZÁS, E. A study of cryptosporidiosis in a cohort of neonatal calves. Veterinary Parasitology, Amsterdam, v. 106, n. 1, p. 1117, 2002.

CHARLES, T. P.; CAMPOS, O. F. de; LIZIERE, R. S. Uso do teste de coagulação pelo glutataldeído como indicador do nível de imunoglobulinas no soro de bezerros recémnascidos. Revista da Sociedade Brasileira de Zootecnia, Viçosa, MG, v. 23, n. 1, p. 65-72, 1994.

CUI, J. QIC program and model selection in GEE analyses. Stata Journal, College Station, v. 7, n. 2, p. 209-220, 2007.

De GRAAF, D. C.; VANOPDENBOSCH, E.; ORTEGAMORA, L. M.; ABBASSI, H.; PEETERS, J. E. A review of the importance of cryptosporidiosis in farm animals. International Journal for Parasitology, Oxford, v. 29, n. 8, p. 1269-1287, 1999.

DOHOO, I.; MARTIN, W.; STRYHN, H. Veterinary epidemiologic research. Charlottetown: AVC, 2003. 706 p. 
ECKERT, J.; BRAUN, R.; SHIRLEY, M. W.; COUDERT, P. COST.89/820. Biotechnology: guidelines on techniques in coccidiosis research. Luxembourg: Office for Official Publications of the European Communities, 1995. 300 p.

FAGUNDES, T. F.; VIDAL, L. G. P.; ALVES, P. A. M.; TASSINARI, W. S.; COELHO, S. M. O.; MENEZES, R. C. A. A.; FONSECA, A. H.; PEREIRA, M. J. S. Análise descritiva da diarreia em uma coorte de bezerras criadas em sistema de casinhas até cem dias de idade, Município de Piraí, Estado do Rio de Janeiro, Brasil. Semina: Ciências Agrárias, Londrina, v. 35, n. 4, p. 1895-1912, 2014.

FRANK, N. A.; KANEENE, J. B. Management risk factors associated with calf diarrhea in Michigan dairy herds. Journal of Dairy Science, Champaign, v. 76, n. 5, p. 1313-1323, 1993.

FURMAN-FRATCZAK, K.; RZASA, A.; STEFANIAK, $\mathrm{T}$. The influence of colostral immunoglobulin concentration in heifer calves serum on their health and growth. Journal of Dairy Science, Champaign, v. 94, n. 11, p. 5536-5543, 2011.

GARBER, L. P.; SALMAN, M. D.; HURD, H. S.; KEEFE, T.; SCHLATER, J. L. Potential risk factors for Cryptosporidium infection in dairy calves. Journal of the American Veterinary Medical Association, Schaumburg, v. 205, n. 1, p. 86-91, 1994.

GEURDEN, T.; VANDERSTICHEL, R.; POHLE, H.; EHSAN, A.; von SAMSON-HIMMELSTJERNA, G.; MORGAN, E. R.; CAMUSET, P.; CAPELLI, G.; VERCRUYSSE, J.; CLAEREBOUT, E. A multicentre prevalence study in Europe on Giardia duodenalis in calves, with molecular identification and risk factor analysis. Veterinary Parasitology, Amsterdam, v. 190, n. 3-4, p. 383-390, 2012.

HARRELL, F. E. Regression modeling strategies. New York: Springer-Verlag, 2001. 572 p.

HASCHEK, B.; KLEIN, D.; BENETKA, V.; HERRERA, C.; SOMMERFELD-STUR, I.; VILCEK, S.; MOESTL, K.; BAUMGARTNER, W. Detection of bovine torovirus in neonatal calf diarrhoea in lower Austria and Styria (Austria). Journal of Veterinary Medicine, Oxford, v. 53, n. 4, p. 160-165, 2006.

HIN, L. Y.; LAU, T. K.; ROGERS, M. S.; CHANG, A. M. Dichotomization of continuous measurements using generalized additive modelling-application in predicting intrapartum caesarean delivery. Statistics in Medicine, Hoboken, v. 18, n. 9, p. 1101-1110, 1999.

HIN, L. Y.; WANG, Y. G. Working-correlation-structure identification in generalized estimating equations. Statistics in Medicine, Hoboken, v. 28, n. 4, p. 642-658, 2009.
HØJSGAARD, S.; HALEKOH, U.; YAN, J. The R package geepack for generalized estimating equations. Journal of Statistical Software, Los Angeles, v. 15, n. 2, p. 1-11, 2006.

JIMÉNEZ, A. E.; FERNÁNDEZ, A.; ALFARRO, R.; DOLZ, G.; VARGAS, B.; EPE, C.; SCHNIEDER, T. A cross-sectional survey of gastrointestinal parasites with dispersal stages in feces from Costa Rican dairy calves. Veterinary Parasitology, Amsterdam, v. 173, n. 3-4, p. 236-246, 2010.

KATZ, M. H. Multivariable Analysis. A practical guide for clinicians. Cambridge: Cambridge University, 2006. $203 \mathrm{p}$.

LEVINE, N. D. Veterinary protozoology. Ames: Iowa State University Press, 1985. 414 p.

LIANG, K. Y.; ZEGER, S. L. Longitudinal data analysis using generalized linear models. Biometrika, Oxford, v. 73, n. 1, p. 13-22, 1986.

MACHADO NETO, R.; FARONI, C. E.; PAULETTI, P.; BESSI, R. Levantamento do manejo de bovinos leiteiros recém-nascidos: desempenho e aquisição de proteção passiva. Revista Brasileira de Zootecnia, Viçosa, MG, v. 33, n. 6, p. 2323-2329, 2004.

MALDONADO-CAMARGO, S.; ATWILL, R. E.; SALTIJERAL-OAXACA, J. A.; HERRERA-ALONSO, L. C. Prevalence of and risk factors for shedding of Cryptosporidium parvum in Holstein Freisian dairy calves in central México. Preventive Veterinary Medicine, Amsterdam, v. 36, n. 2, p. 95-107, 1998.

MATJILA, P. T.; PENZHORN, B. L. Occurrence and diversity of bovine coccidia at three localities in South África. Veterinary Parasitology, Amsterdam, v. 104, n. 2, p. 93-102, 2002.

MENEZES, R. de C. A. A. de; LOPES, C. W. G. Epizootiologia da Eimeria arloingi em caprinos na Microrregião Serrana Fluminense, Estado do Rio de Janeiro, Brasil. Revista Universidade Rural, Série Ciências da Vida, Seropédica, v. 17, n. 2, p. 5-12, 1995.

MOHAMMED, H. O.; WADE, S. E.; SCHAAF, S. Risk factors associated with Cryptosporidium parvum infection on dairy cattle in southeastern New York State. Veterinary Parasitology, Amsterdam, v. 83, n. 1, p. 1-13, 1999.

MUHID, A.; ROBERTSON, I.; NG, J.; YANG, R.; RYAN, U. Prevalence of Giardia spp. infection in preweaned and weaned calves in relation to management factors. Veterinary Journal, Amsterdam, v. 191, n. 1, p. 135-137, 2012. 
NELDER, J.; WEDDERBURN, R. Generalized linear models. Journal of the Royal Statistical Society. Series A, London, v. 135, n. 3, p. 370-384, 1972.

NUMABE, T.; OIKAWA, T.; KIKUCHI, T.; HORIUCHI, T. Birth weight and birth rate of heavy calves conceived by transfer of in vitro or in vivo produced bovine embryos. Animal Reproduction Science, Amsterdam, v. 64, n. 1-2, p. 13-20, 2000.

OliVEIRA, A. A. de; AZEVEDO, H. C.; MELO, C. B. de. Criação de bezerras em sistemas de produção de leite. Brasília: EMBRAPA, 2005. 8 p. (Circular técnica, n. 1). Acesso em: <http://www.cpatc.embrapa.br/ publicações_2005/ct-38.pdf>. Acesso em: 24 abr. 2012.

PAN, W. Akaike's information criterion in generalized estimating equations. Biometrics, Washington, v. 57, n. 1, p. 120-125, 2001.

PÉREZ, E.; KUMMELING, A.; JANSSEN, M. M. H.; JIMÉNEZ, C.; ALVARADO, R.; CABALLERO, M.; DONADO, P.; DWINGER, R. H. Infectious agents associated with diarrhoea of calves in the canton of Tilarán, Costa Rica. Preventive Veterinary Medicine, Amsterdam, v. 33, n. 1-4, p. 195-205, 1998.

PIMENTA-OLIVEIRA, A.; OLIVEIRA-FILHO, J. P.; DIAS, A.; GONÇALVES, R. C. Morbidity-mortality and performance evaluation of Brahman calves from in vitro embryo production. BMC Veterinary Research, London, v. 7, n. 79, 2011.

QUÍLEZ, J.; SÁNCHEZ-ACEDO, C.; Del CACHO, E.; ClaVEl, A.; CAUSAPÉ, A. C. Prevalence of Cryptosporidium and Giardia infections in cattle in Aragón (northeastern Spain). Veterinary Parasitology, Amsterdam, v. 66, n. 3-4, p. 139-146, 1996.

R DEVELOPMENT CORE TEAM - R: a language and environment for statistical computing. Vienna: $\mathrm{R}$ Foundation for Statistical Computing, 2011. Available at: $<$ http://www.R-project.org>. Accessed at: 15 set. 2011.

RAY, J. H. B. El ternero: volumen II nutrición y patologia. Zaragoza: Acribia, 1972. $199 \mathrm{p}$.

RIBEIRO, M. F. B.; BELÉM, P. A. D.; SALCEDO, J. H. P.; FARIA, J. E. de. Hipogamaglobulinemia em bezerros. Arquivo Brasileiro de Medicina Veterinária e Zootecnia, Belo Horizonte, v. 35, n. 4, p. 537-546, 1983.

ROBERTS, F. H. S.; O'SULLIVAN, J. P. Methods for eggs counts and larval cultures for strongyles infesting the gastrointestinal tract of cattle. Australian Journal of Agricultural Research, Victoria, v. 1, n. 1, p. 99-102, 1950.
SCARPATI, M. T.; LÔBO, R. B. Modelos animais alternativos para estimação de componentes de (co) variância e de parâmetros genéticos e fenotípicos do peso ao nascer na raça Nelore. Revista Brasileira de Zootecnia, Viçosa, MG, v. 28, n. 3, p. 512-518, 1999.

SIVULA, N. J.; AMES, T. R.; MARSH, W. E.; WERDIN, R. E. Descreptive epidemiology of morbidity and mortality in Minnesota dairy heifer calves. Preventive Veterinary Medicine, Amsterdam, v. 27, n. 3-4, p. 155171, 1996.

STOTT, G. H.; WIERSMA, F.; MENEFEE, B. E.; RADWANSKI, F. R. Influence of environment on passive immunity in calves. Journal of Dairy Science, Champaign, v. 59, n. 7, p. 1306-1310, 1976.

SVENSSON, C.; LUNDBORG, K.; EMANUELSON, U.; OLSSON, S.-O. Morbidity in swedish dairy calves from birth to 90 days of age and individual calf-level risk factors for infectious diseases. Preventive Veterinary Medicine, Amsterdam, v. 58, n. 3/4, p. 179-197, 2003.

TENNANT, B.; BALDWIN, B. H.; BRAUN, R. K.; NORCROSS, N. L.; SANDHOLM, M. Use of the glutaraldehyde coagulation test for detection of hypogammaglobulinemia in neonatal calves. Journal of the American Veterinary Medical Association, Schaumburg, v. 174, n. 8, p. 848-853, 1979.

TZIPORI, S. The aetiology and diagnosis of calf diarrhoea. Veterinary Record, London, v. 108, n. 24, p. 510-514, 1981.

UENO, H.; GONÇALVES, P. C. Manual para diagnóstico das helmintoses de ruminantes. 4. ed. Tóquio: Japan International Cooperation Agency, 1998. 143 p.

WELLS, S. J.; DARGATZ, D. A.; OTT, S. L. Factors associated with mortality to 21 days of life in dairy heifers in the United States. Preventive Veterinary Medicine, Amsterdam, v. 29, n. 1, p. 9-19, 1996.

WINDEYER, M. C.; LESLIE, K. E.; GODDEN, S. M.; HODGINS, D. C.; LISSEMORE, K. D.; LEBLANC, S. J. Factors associated with morbidity, mortality, and growth of dairry heifer calves up to 3 months of age. Preventive Veterinary Medicine, Amsterdam, v. 113, $\mathrm{n}$. 2, p. 231-240, 2014.

WOOD, S. N. Generalized additive models: an introduction with R. London: Chapman and Hall/CRC, 2006. $410 \mathrm{p}$.

YAN, J. Geepack: yet another package for generalized estimating equations. $R$ News, Vienna, v. 2, n. 3, p. 1214, 2002. 
YAN, J.; FINE, J. P. Estimating equations for association structures. Statistics in Medicine, Hoboken, v. 23, n. 6, p. 859-880, 2004. 